\title{
Conservationist governmental technologies in the Western European mountains: the unfinished transformation of the Pyrenees
}

\author{
Ismael Vaccaro, McGill University, Canada ${ }^{1}$ \\ Oriol Beltran, Universitat de Barcelona, Spain
}

\section{Introduction}

This paper, using the theoretical framework provided by political ecology, examines the impacts of state-making technologies in several areas of a first-world landscape in the Pyrenean mountain range. The Pyrenees are the mountainous range over which the contemporary border between France and Spain is located (Sahlins 1991). Using regional examples, this paper discusses processes of governmental territorialization and shows how they relate to natural resources conceptualization and management with an emphasis on the political inequalities that act as a framework for these processes (Blaikie 1989; Bryant and Bailey 1997). We historicize the influences of public agencies on territory and natural resources, and discuss the ideological framework that sustains this, while also analyzing its social and political impacts on people and landscape.

One rationale for the paper is that the vast majority of governmentality and territorialization studies have been conducted in postcolonial locales and in developing countries subject to colonial influence. This also applies to the work of political ecologists, whose work was initiated by analysis of the political economy of resources in developing countries. In many studies, therefore, the emphasis has been on the dissonances between metropolis and colonies as well as its acculturating effect (Chackrabarty 2000). During the last decade, however, different voices inside political ecology have called for the inclusion of the first-world into its analytical gaze (Robbins 2002; Walker 2003). The inclusion of developed locales provides the analysis with very different contexts (yet similar processes) of territorialization. The comparison of both contexts creates a space from which to rethink such phenomena. The analytical goals of this paper are, therefore: 1) to shift the emphasis of the political ecological analysis from an explanation of territorialization based on the tension between the first and third worlds, towards the impact of the conflictive relationship between cities and rural areas in a European context, 2) to highlight the resilience and creativity of local agency in the face of massive political disruption in the form of public policies, 3) to point out the emergence of European policies and the new leisure economies as key elements of the contemporary reconstruction of the Western Pyrenees, and 4) to underscore the unfinished character, or the ongoing nature, of the political negotiation of rights, access and control of natural resources in the region.

In numerous locales across the world, political ecological research has proven that conservation, and one of its modern counterparts, tourism, need to be understood as social processes with significant political consequences (Escobar 2008; Neumann 1998; West et al. 2006). Conservation policies to preserve both wildlife and habitats, and tourism activities for that matter, require a profound reconceptualization of space and natural resources (Vaccaro and Beltran 2007a; Zimmerer 2006). This means that conservation implies a fundamental change to the jurisdiction and the ownership regimes of protected areas. Conservation and other policies designed to manage natural resources, embody a specific form of governmentality with territorial consequences. Agrawal (2005) has coined the term environmentality to identify this specific form of governmentality. The state intervenes and assumes high levels of control of a specific territory: control that may translate to the interdiction of local management, production systems, or practices. Consequently, ecological conservation has become a vehicle for governmental intervention over territories, redefining them and, in turn, redefining the collective national identity as a whole (Cederlöf and Shivaramakrishnan 2006; West 2006). Conservation policies, thus, always imply some level of external appropriation of the 'local'. Ski resorts and massive numbers of second residences share some characteristics with the aforementioned conservation policies: they are consumers of space, and they redefine this space and its uses according to needs defined externally, usually from urban centers (Cronon 1991; Sassen 2006; Williams 1972).

\footnotetext{
${ }^{1}$ Ismael Vaccaro, Assistant Professor, Dept. of Anthropology (and School of Environment), McGill University, 838 Stephen Leacock Building, 855 Sherbrooke Street W., Montreal, Quebec, H3A 2T7, Canada. ismael.vaccaro "at" mcgill.ca. Oriol Beltran, Professor of Social Anthropology, University of Barcelona, Spain. obeltran"at" trivium.gh.ub.es.
} 
We must not give the impression, however, than rural areas in Europe are just disenfranchised and peripheral, pushed back and forth by the vagaries of markets and remote bureaucrats. These areas, even if they are suffering depopulation or economic collapse (Ayuda and Pinilla 2002; Molina 2002; Sabartés 1998), have always shown high levels of resilience and striking creativity to adapt and take advantage of the changes driven from afar (Frigolé 2007; Vaccaro 2007). Plenty of local people still live in the Pyrenees, and this is important. To understand the interactions between conservation and society in the Pyrenees one must look at the interactions between a "metropolitan-secular view of nature and its economistic and material uses for the nation" and "an indigenist, or regionalist, reaction to the expansion of the high-modern nation-state (...) or to the forces of globalization that intervene from outside the realms of the modernstates" (Cederlöf and Sivaramakrishnan 2006, 7). In other words, every conservation project presents a social and ideological tension between external and local goals, methods, and values.

\section{Questions of modernity}

To study the massive social and ecological transformations that often are the locus of political ecological research, it is important to understand the political and economic regimes that inform landscape management policies (Escobar 2008). The contemporary global hegemonic regime has been dominated by an elaborated form of 'modernity' since the eighteenth century. This section describes the inception of this concept and introduces its main characteristics: the nation-state as a political structure, and capitalism and mass production as an economic framework (Harvey 2006; Smith 1990). The emphasis of this section, however, is that the inherent inequalities generated by this regime exist not only at an international scale (Wallerstein 1974), but also exist inside most nation-state units, developed and undeveloped (Ferguson 1994). The expansion of the analytical gaze of political ecology from the third-world to the first-world has allowed us to identify these inequalities and tensions in Spain, the US, and France (McCarthy 2003). Consequently, our discussion of the causality behind these inequalities has shifted from an analysis of the consequences of the colonial and postcolonial domination to an analysis of the impact that the global urban system (the global network of centers of consumption) exerts over areas of production and influence (Castells 1996; Vaccaro and Beltran 2007a).

The establishment of systematic, scientifically organized, forms of governmentality over territory (Gellner 1983; Hannah 2000), people (Agamben 1998; Haraway 1991), and natural resources (Peluso and Vandergeest 2001; Sivaramakrishnan 1999) is a distinctive feature of the emergence of modernity. Modernity, as a concept, encapsulates a form of society that emerged in the Western European countries between the late eighteenth and the early twentieth centuries (Foucault 2007). During this period these societies experienced the blossoming of modern nation-states and the consolidation of their market economies.

There has been considerable theoretical attention devoted to the concept of Modernity and its emergence (Polany 1944; Hardt and Negri 2000). At the end of the Middle Ages, European elites were concentrated in the booming cities of the continent with abundance of resources, namely populations, businesses and wealth. Most aristocracy, uncontested rulers of the countryside, had fled their domains long before to join the urban royal courts. This effervescence fostered productivity and the raising of a new social class, which emerged from the ranks of urban merchants and artisans: the bourgeoisie. During the eighteenth and nineteenth centuries these elites concentrated in cities, in a process of traumatic transition, were building a new economic system on the foundations established by the pioneers of the Scientific Revolution. The ideological achievements of the Enlightenment and the trade networks generated by mercantilism generated a novel ideological framework which informed the creation of the new nation-states and their newly associated productive regimes (Gellner 1983; Sassen 2006; Scott 1998). The Enlightenment emphasized individualism, democracy, universalism, and industriousness, establishing the ideological parameters for a social revolution. This process occurred in places such as Paris and London, where the medieval urban and agricultural structure could not cover the needs of its overflowing population.

Urban workshops grew as social and technological assets adapted to new productive goals and working needs. Very soon the Medieval socio-productive structure, characterized by small occupational units and guilds, became outdated. Large investments of capital, technology and the systematization of productive processes generated the first factories (Hobsbawm 1968; Thompson 1999; Thomson 1992). Capitalism, as a mode of production, is an essential concept to understand the appearance of modernity. It is characterized primarily by the concentration of the means of production in a few elite hands; the 
monetization of economic relations; the implementation of technology and labor regulations set out for mass production; and an obsessive effort to increase interconnectivity at all levels.

Mass production in factories, and new social places of production, concentrated manufacturing. The factories also became living spaces where social structures, everyday life practices and timings adapted to the productive process while providing the material basis for the reproduction of the labor force (Attali 1982; Terradas 1979). The extended family, as an integrated domestic productive unit, amidst a community of similar units, was replaced by a structure in which the work in the factory became central and detached from social relations such as, for instance, kinship or religion. A much discussed effect of modernity is the fragmentation of individual and collective identity (Certeau 2002), which previously had been closely linked to an integrated perspective of social life: the statalist capitalist society leads to the individuation of its subjects resulting in the dismantling of the previously predominant domestic system (Mitchell 1991).

This economic transformation, the Industrial Revolution, coincided with the emergence and consolidation of nation-states with their need for homogenization of territory, resources and individuals who became citizens (Gellner 1983; Polanyi 1944). The capitalist mode cannot be detached from the simultaneous deployment of nationalism, the modern state and its overarching professionalized bureaucracy (Weber 1978). The birth of modern nation-states, omnipresent and almost omnipotent social regulatory institutions, seems to constitute a fundamental ideological paradox, an identity marker that defines modernity: a paradox that simultaneously sets freedom against control, individualism versus state (Agamben 1998; Foucault 1991, 2008; Hetherington 1997). This occurred at the same time that the concepts such as individualism and biopolitics were re-invented and approved as a basic ideological core of the new societies. Democratic contractualism became the expected legitimate ideological form of government. "Reason", as the overarching tool developed by the Enlightenment, became the foundation of a new order of universalizing goals and values designed to achieve the individuation of personal identities in the frame of a democratic organization of society (Habermas 1991).

This is, tout court, the Euro-centered and urban-driven and hegemonic "origin story" of modernity, a historical projection deeply interconnected with nineteenth century historiography, colonialism, and the idea of progress.

Modernity quickly, almost immediately following its ideological inception, became a self assuring discourse with legitimizing, transformative and coercive powers. It developed into a direct inheritor of previous narratives elaborated to deal with various types of otherness, such as savagery, barbarism, paganism, primitivism or otherwise uncivilized society. "To modernize" thus, joined other historical salvage narratives such as "to evangelize" or "to civilize" devised to transform inadequate 'others' into acceptable 'us' (Bestard and Contreras 1987). These discourses were centered on representing the other as essentially inferior, an inferiority that legitimized all sorts of physical, political and intellectual appropriations. In the case of modernity, its expansion and its potential as a legitimizing idea is inextricably linked to the concept of development. Often the usage of the concept of development has been restricted to post-World War II efforts to modernize a third world country in the process of reaching nominal political independence (Escobar 1995; Martinussen 1997). Postcolonial development discourses emerging from the "development community" and the autochthonous elites, however, have striking similarities with the discourses that predominated all across Europe during the modernization fever that swept the world with the definitive consolidation of the industrial revolution in the mid-eighteenth century (Fairhead and Leach 1996; Ferguson 1994).

Postcolonial theory, in general, has assumed a monolithic Europe, a homogeneous category encompassing the developed western countries. The colonial experience began long before capitalist modernity was massively exported and implemented in the colonies by the European powers. The forced implementation of this particular modernity was simultaneously happening in the colonies and the "remote" inlands of Europe. States were expanding and taking control of territory, expropriating land, delegitimizing local managerial institutions, measuring and censoring people and resources simultaneously on several continents, including Europe (Iriarte-Goñi 2002; Pred 1986; Sabetti 2002). Technologies of the self were similarly applied to individuals of the metropolis or the periphery in order to proletarianize them, to colonize them, to push them out from fields and domestic workshops, and to integrate them into massive production systems characterized by concentrated means of production and salaried work (Kriedte et al. 1986; Thompson 1968).

The implementation of capitalist modernity is an expansive process that deploys cities to the western inlands and to the colonies from the late eighteenth century onwards. The urban experience, as a process of densification of social relations, is at the heart of modern capitalist identity (Sassen 2006).

Journal of Political Ecology $\quad$ Volume 17, 2010 
Subaltern populations of the western inlands seem to 'suffer' the same process of remodeling and expropriation as the colonial peoples in the emerging third world (Foucault 2007). The changing technologies of government that characterize the process of modernization experienced by societies across the globe between the eighteenth and the twentieth centuries, including how states interact with localities, new regulatory bodies, and the creation of environmental subjects, were implemented on rural Europeans as much as among the new colonial subjects (Agrawal 2005).

\section{Environmental governmentality in the Pyrenees}

\section{Expanding the state over the mountains: a political genealogy of the territory}

If we now apply these ideas to the specific case of the Pyrenees, the presence of the state before the nineteenth century was, at best, intermittent and often mediated by aristocratic jurisdiction. Beginning in the 1820s the emergent modern Spanish State underwent a radical administrative restructuration of its territory in search for efficiency and managerial rationalization (Burgueño 2000; Sabaté 1997). The creation and standardization of municipalities on-the-ground constitutes the first modern wave of state driven territorialization of the mountains. The criteria used to confer municipal status were elements such as minimum demographic size, connectivity to markets, and economic viability. Only the local communities that complied with those criteria could reach the status of municipality and thereby receive public services. Smaller communities did not achieve this legal status. The inhabitants of the farms and villages of the slopes were forced, more than ever, to migrate down to the valleys. As they had no access or rights to public services, they had to relocate in the larger villages of the valleys to buy supplies, to bring children to school, to issue all kinds of legal permits, search for trading and marriage partners, and so on.

Starting in the mid nineteenth century the state began a new form of territorialization: the so-called disentailment campaigns (1850-1900). The disentailment campaigns consisted of the introduction, via expropriation, of theoretically non-productive lands into the real estate market. Common property, abundant at the time in the Pyrenees, was especially targeted (Gil 2000; Iriarte-Goñi 2002). Non-private forms of property, in the eyes of the nineteenth century Spanish liberals, were inefficient.

The beginning of the twentieth century witnessed the consolidation of yet another expropriation campaign led by the forest engineer corps (1900-1960). The forest corps of engineers (Cuerpo de Ingenieros Forestales) was given the authority to regulate land uses. It was a time in which dozens of water reservoirs were being built downstream and there was a lot of concern about deforestation and erosion affecting the efficiency of the reservoirs: thousands of hectares were thus expropriated by the state. Grazing and other traditional land uses were considered harmful and were believed to cause erosion (Gómez 1992). The confiscated land was enclosed, kept, and managed by governmental institutions. The people that had lived and worked on farms, now expropriated, had to relocate. Often, this meant that they too moved to the valley towns. Following the disentailment and the expropriation campaigns, large areas of the mountains came under public ownership.

As a result of its recent history, including the recent territorialization policies, the Pyrenees are now characterized by low population densities, communities mainly concentrated in villages, mountains mainly devoid of permanent inhabitants, and exuberant and recovering forests. These new characteristics attracted yet a new wave of territorialization policies. This new wave was characterized by the generalized implementation of conservation areas. Public land accumulated during the previous waves of state expansion acted as the territorial core of the soon-to-expand new parks and reserves.

The rationale behind the last three phases of state-endorsed territorialization were legitimized, respectively, by the claim that, first, common lands were not being putted to good use; that, second, traditional agricultural practices were harmful for the landscape; and, third, that biodiversity needs to be protected by non-local institutions such as parks.

The three cases are examples of an external intervention that is justified by the claim that local environmental management is unsound for economic or ecological reasons. This assertion is frequently made by powerful institutions against weaker ones, as political ecologists have frequently noted (Agrawal 2005; Blaikie 1989; Fairhead and Leach 1996). National, metropolitan concerns, take precedence over regional and local uses (Cederlöf and Sivaramakrishnan 2006). These changes are certainly associated to the extension of the public jurisdictions over the peripheral areas of the nation (Vaccaro 2005). 


\section{A landscape of ideas: bureaucrats, bears and fields}

In May 2005 we had an interview with a high official of the Catalan governmental agency of environment, natural parks section (Departament de Medi Ambient i Habitatge). The goal of the meeting was to explain our research projects in the High Pyrenees, an area in which a new park was being implemented. The research intended to analyze the history of the social variables that have affected the landscape that his organization was trying to protect with a park. In other words, the Pyrenees are a heavily humanized landscape, and its ecological values (those that warrant their conservation) are a result of a long history of local management. To effectively protect these mountains and its current ecological morphology, we contended, we also need to understand this history.

After more than an hour of conversation the official said, "bottom line is that right now we are only interested in the production of baseline data". By baseline data he was referring exclusively to ecological data (i.e. non-human species distribution). In his mind, social data was neither basic nor relevant to the design and implementation of the proposed conservation policy. Reflecting on our incapacity to convey ideas that in our understanding were fundamental, we asked if we would get their support to conduct research if we could come up with independent funding. He thought it was reasonable. And we parted ways.

A few months later we identified a potential funding source. The grant required a local non-public institution from the research area to vouch for the study. We had also identified an environmental NGO that was excited about the research and willing to support us. Three days before the deadline the NGO phoned to tell us that they had received several calls from the agency of environment "advising not" to support such a project. The NGO, depending on subventions and public permits, apologetically removed its support. Interestingly enough, other local institutions heard about this incident and supported the research project. The project went on to receive its backing and its funding (Beltran and Vaccaro 2008).

At the same time, not too far to the north, the French government continued with its relentless implementation of its brown bear project. The original stated goal of the project was the reinforcement of the Pyrenean brown bear population by releasing a handful of Slovenian specimens. The reintroduction of predators in relatively populated areas with livestock and humans is always a controversial endeavor (Bjerke et al. 1998; Knight 2006; Mech 1991). This project has encountered heavy local opposition including road blockades, nocturnal distribution of poisoned bait, demonstrations, "accidental" shootings of isolated bears, and political challenges from local institutions (Jimenéz 1999).

It cannot be forgotten that the vanishing of the brown bear was recent, and the result of deliberate hunting. There are records of the last kills in the early and mid twentieth century: 1948 in the Pallars Sobirà (Casanova 1997). The names of the hunters are known. Pyrenean communities were going about the removal of potentially dangerous competitors. This new project tries to undo what it took generations of locals to accomplish.

After a fairly calm period, during the Fall of 2008, an encounter between a bear and an elderly hunter in the Val d'Aran resulted in minor injuries to the hunter. The incident triggered a heated chain reaction, with local cries for the removal or death of the bear, and a widespread reaction by environmental groups and urban populations against such local demands. On both sides, all sort of unfair characterizations were used to rally supporters: some media depicted bears as bloodthirsty menaces while others reflected on the backwardness of locals interested only on hunting and real estate speculation. In an interesting anthropomorphizing or domesticating attempt, each one of the released bears has been given a name. The bear in question, named Hvala, had been godmothered in 2006 by the very popular wife of the current President of France. Eventually the first snow fell and the bear disappeared before anything could happen. The event, however, clearly unveiled deep social fractures associated to the perception and management of wildlife: "We do not give a hoot about the views of Parisians, civil servants or the wife of the president" (Louis Dollo, quoted in Bremner and Tourres 2008).

From a political ecology perspective the genesis and implementation of this project is a paradigmatic example of public agency centralizing and monopolizing knowledge and practice. A central agency of the French state was in charge of designing and taking all the decisions and there was no input from the territory. Originally the project was pushed by the French Ministry of the Environment, without much consultation with the scientific committee of the Pyrenees National Park or the local institutions on the French side of the border. The release of animals was not coordinated with the Spanish authorities. The subsequent resistance at all levels triggered some negotiations. Interestingly enough, the bear reintroduction 
has become a national issue that separates the majority of French society, overwhelmingly in favor of the project, from local Pyrenean communities, who are mostly against it.

During these debates, scientists determined that the species of native Pyrenean bears was extinct. This fact has a conceptual capital importance. Suddenly it was clear that the goal was not to protect threatened biodiversity but to restore or to reinvent a landscape. The genetic makeup of the replacement bears, after all, was Slovenian, not Pyrenean. The introduction of bears in the Pyrenees as well as the massive implementation of protected areas over the range questions the idea of a "social" landscape (Welch-Devine 2007; Vaccaro and Beltran 2007a). Behind the discourse of ecosystem balance or environmental restoration, there is a disregard for the role of humans in the environment, or for local livelihoods. Local communities suspect that the Pyrenees have been planned by the state as a gigantic zoo, or as a leisure reservoir.

The considerations on biodiversity that emerge from this discussion of bear reintroduction nicely introduce another significant element: the progressive vanishing of traditional montane agriculture, resulting in an important loss of anthropogenic features of the landscape, and with them, of biodiversity. Traditional mountain agriculture included cultivation of the scarce flat areas at the bottom of the valleys around the villages and the small fields around the high elevation huts where the herds and people summered. Currently these fields are mostly abandoned or have been shifted to pastures for cattle fodder. The intensification of economic flows that accompanied the modernization of western European societies eliminated incentives for the practice of montane farming and grazing. It was cheaper to buy cereals and vegetables from the more productive farmland situated on the plains.

Traditional agriculture can be associated with biodiversity at two levels. Historically farmers from all over the world have developed seed varieties specifically adapted to the local conditions. This domestic agro-biodiversity is currently in rapid decline in most rural areas. The economic mechanics of modern capitalism do not favor locally adapted, low productivity seeds. The market looks for high yielding varieties, and monocropping situations ensue. At the same time, the mountains, characterized by combinations of forest and grassland, have a higher degree of ecosystemic diversity and potential when there are numerous cultivated fields at several elevation stages. In the past, all sorts of species benefited from the presence of these alimentary rich patches.

Landscape ecology acknowledges that ecotones (transition patches between large habitat areas) are especially rich in biodiversity because of the overlapping of species from both sides of the ecotone and the species that mingle in the gray area in between (Forman 1995). Traditional agriculture, with its low-impact practices and its high variety of local forms of seeds and farm animals, has been recognized as contributing to biodiversity in its own right (Altieri 1995). The cohabitation of traditional agriculture with a heterogeneous montane mosaic (forest, glades, alpine meadows, and so on) seems to be the perfect setting to preserve biodiversity. Today, parks are almost exclusively covering the upper parts of the ranges, ignoring the valleys. The result is that, with the lack of cultivation, the fields are disappearing, and with them their associated ecology. Agricultural areas are not part of the conservationist goals in establishing reserves and parks. "Forest species were the most endangered, more in need of protection. Besides, the rural flight has left almost no cultivated land inside the borders of the park. It is not part of our mandate" (personal interview of a park official). The ecological homogenization of the landscape via forest expansion is a predictable outcome of the ideas of nature that informed the design of the conservation policies of the area.

The three elements presented in this section, a) our misunderstandings with the administration, b) the bear restoration project, and c) the different uses and concerns attached to the concept of biodiversity, provide us with interesting entry points to discuss the conservation biology operations of the state on the ground. The public agency over the territory is legitimized by a two important elements: a) the state attributes itself the capacity to identify the common good, and b) the representatives of the state, bureaucrats and specialists, who derive their authority from their belonging to a public institution and from possessing specific systematic, socially sanctioned knowledge. Both characteristics build the base for a quasi-monopoly of territorial management and conservation policies.

Although individual behavior cannot be excluded as an explanation for our misunderstandings with the administration, the dislike for independent assessment of a public agency is a common trend in public institutions. Also, environmental institutions, while becoming increasingly more conscious of the relevance and impact of humans over nature, are still predominantly occupied by biologists or engineers, and their mandate, after all, is to protect natural wildlife and habitat. The analysis and inclusion of social variables present in a given landscape can only result in the empowerment of the local population that

Journal of Political Ecology $\quad$ Volume 17, 2010 
practices them, especially if distinctive, valuable, ecological features are deemed to be of anthropogenic origin. Current conservation policies in the Pyrenees may include consulting local councils, but the ultimate jurisdiction lies with the state and its representatives.

The bear project constitutes a more radical example of this dissonance between local and national/governmental ideas of what is a good managerial practice. In both sides of the border the montane districts are struggling to keep their ranching activities viable, at the same time that tourism is in a process of expansion. To recolonize rangeland with bears does not seem to fit with the local developmental agenda. The unwavering hand of the French state in this matter, with scarce communication or collaboration with their Spanish counterparts, and overlooking the abundant local opposition, do account for an institutional blind faith on the need to preserve the bear (a national good) and the accuracy of the assessments produced by the policy designers and managers. This is yet another example of a metropolitan view of nature, supported by public policies, that ignores the regional perspective. The expected outcome of this unilateral imposition is the emergence of a wide array of resistance practices (Scott 1985).

A mountain range that is now reaching $50 \%$ of territorial enclosure in protected areas where the bear (and maybe the wolf) is reintroduced, is a reinvented landscape, one that is orderly managed to become "wild". It has to be carefully ordered because it is competing, or collaborating, with another territorial project centered on the implantation of different forms of tourism (ecotourism, ski resorts, cultural museums, or second residences). The monopoly that the state attempts to consolidate on conservation and scientific management of the territory, as shown by the examples provided in this section, is based on a quasi-Weberian bureaucratization of this managerial field. The goal is a territorialization of resources grounded on a simplification of the landscape focused on the management of organized wilderness (Peluso and Vandergeest 2001; Scott 1998).

\section{Europe, the market, and the people with abundant history}

In recent years, in addition to the formative hand of states present in the Pyrenees, a new political entity has started to show some level of influence in the area's management of natural resources. The European Union is generating policies on all sorts of issues that snowball across the European mountains.

The elimination of migratory and economic boundaries inside the Union after the signature of the Schengen treaty has had significant consequences. As pointed out by Perramond (2007), the effective economic integration of Western Europe resulted, amongst other things, in the unification of the European real estate market. Different European countries have different levels of wealth. In general north European citizens have higher earnings and consumption potential than southern Europeans. Northern Europeans have purchased properties and taken vacations in southern Europe for many decades. Perramond describes the arrival of north Europeans in several areas of the Eastern Pyrenees, in both sides of the border. Isolated houses or clusters of them are bought primarily by Dutch or British citizens.

Although not the result of a direct, locally focused policy, this widespread deregularization of real estate transactions is allowing for a re-territorialization of the European mountains. As Perramond points out, this reorganization, regulated by market mechanisms, has the potential to affect local communities' collective identity, as well as the ways in which commonly owned natural resources, still abundant in the area, are managed. The arrival of these external inhabitants has re-awakened local discourses of identity reification, reinforcing the specific characteristics of local cultural specificity as a way to establish identity boundaries that could allow them to protect their control of local issues and resources.

Nowadays the European Union is more close to a macroeconomic project that a social reality. The EU has also generated a unified real estate market. The unequal access to monetary resources inside the boundaries of the European Union sets the stage for rural gentrification and, perhaps, unjust market driven reappropriation of resources. However the corresponding local reinforcement of identity markers seems to be drawing on a local moral economy to build enough legitimacy to resist a market driven reterritorialization of the social landscape of the Pyrenees.

Another significant group of Brussels-generated policies that have become relevant to Pyrenean communities are agricultural subsidies. European agrarian policies have attempted to provide compensations to rural producers to stay in their fields and in business. Ranchers get subsidies according to the number of cattle or sheep. This is connected with the fact that these areas have suffered intense depopulation and therefore there is less competition for grazing land. The implementation of agricultural subsidies has provided a secure cash-flow associated with ranching and incentives for specialization. Larger herds have emerged as farmers have consolidated. Those that still live on the mountains and that still have 
animals have tended to accumulate more animals. "The link between the Common Agricultural Policies and herd size is arguably more direct. As raisers are paid per head of cattle, sheep, or goats, they have an incentive to maintain as large a herd as is feasible for them" (Welch-Devine 2007, 49). The traditional montane productive patterns were usually characterized by diversification to address potential hardship affecting one or more of the crops or the herds. As a consequence most households use to have a few animals of each kind (pigs, goats, sheep, and cows). Animals were not raised for a commercial, hungry international market, but for subsistence or local trade.

Interestingly enough, the fact that husbandry in the mountains, traditionally not driven by a strong profit motive, may provide some levels of income, has also led to local institutional creativity. Groups of ranchers have created associations that, using norms borrowed from the old commons, allow them to reduce costs by taking advantage of economies of scale: i.e. one big communal herd requires only one full time herder. In la Pobla de Lillet and Castellar de n'Hug one such association has allowed the ranchers to gain enough political weight to be able to negotiate as a group with the areas' natural park management and secure access to previously inaccessible pastures (Vaccaro 2007).

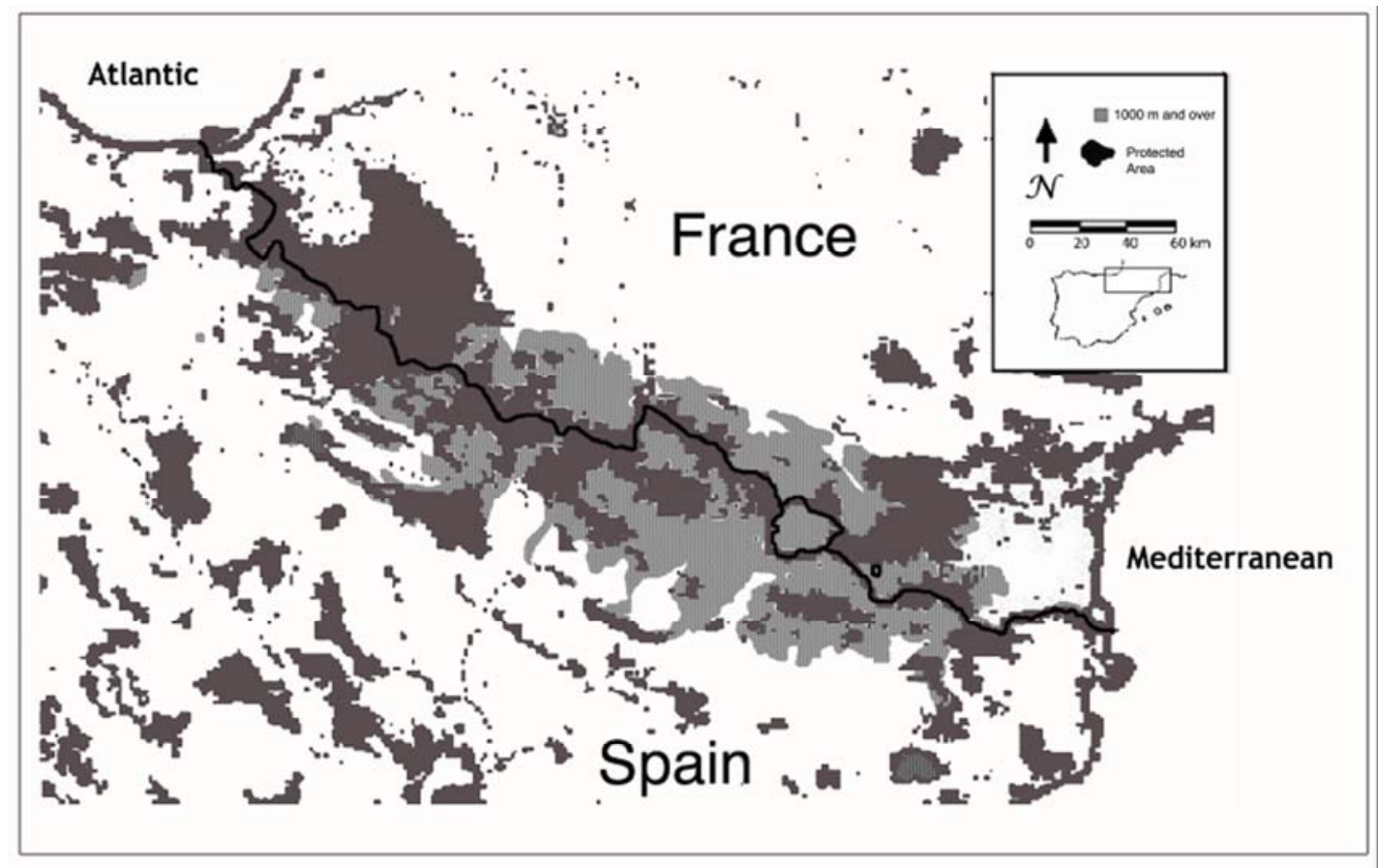

Fig. 1. Protected areas included in the Natura 2000 network around the border between France and Spain. Source: Eionet 2008 (map prepared by L. Zanotti).

These mountains have also been strongly affected by the adoption of the Natura 2000 European directive. Natura 2000 attempts to create a comprehensive network capable of protecting hundreds of valuable habitat types (Welch-Devine 2007). This directive has tended to expand the already existing national networks of protected areas. Conservation has become a major transformative force in the Pyrenees. Most districts of the Catalan Pyrenees, for instance, present between 30 to $70 \%$ of their land area under some level of protection: for example Val d'Aran 58.9\%, Alta Ribagorça 49\%, Pallars Sobirà 69.4\%, Pallars Jussà 34.4\%, and Cerdanya 37.1\% (Fig.1). In the previous section devoted to the different waves of territorialization policies issued by the Spanish state we have already discussed the impact of the jurisdiction and use change implicit on the protection of lands previously used for traditional agro-ranching practices.

In this section we discuss the fact that the European Union has joined the individual states on this redefinition of important sections of the rural areas as collective heritage. The European Union generates a sort of transnational discourse about nature, collective goods, and the public obligation to secure their preservation (Cederlöf and Sivaramakrishnan 2006). This international territorial reconceptualization encounters high levels of mistrust or straighforward resistance from local inhabitants and institutions 
(Murray 2007; Welch-Devine 2007). These conservation policies, resulting from European directives, however, are implemented by the individual states, not by European officials. This internationalization of conservation themes thus, is not resulting on the weakening of the nation-states, but from their territorial reinforcement (Sparke 2005).

Although these conservation policies do not necessarily result in expropriations or prohibition of traditional practices, and have been designed with a battery of compensatory measures, they are commonly perceived as a threat by montane communities. In these regional, local narratives, conservation policies embody the state and a national urban society that does not care for the needs of the 'real' inhabitants of the mountains. It does not matter that conservation policies are opening the door to new types of subsidies. They are intellectually connected by locals to a conceptualization of landscape dominated by the idea of wilderness instead of productive livelihoods. Although Natura 2000 as a policy is not directly connected to the reintroduction of bears, for instance, it is not surprising that both things often appear associated in the regional and local discourses of resistance.

The arrival of northern European neighbors, the expansion of protected areas following European Union mandates, and the impact of agricultural subsidies, are three instances of transnational discourses of nature that result in large scale policies that unfold locally, often with unpredictable effects.

\section{Conclusion}

The discussion of these Pyrenean examples has allowed us to expand the analysis of the political ecology of governance from postcolonial settings to a Western European context. We have extended the analysis to include associated governmental technologies of territorial appropriation, and the general emergency of modernity. The territorial impact of statemaking policies on the peripheral internal areas of the colonizing powers shared striking commonalities with the agency of these same powers in their colonial possessions. These similarities allow us to reconceptualize this asymmetrical relationship between central political hubs and peripheral-appropriated areas. Because of these parallels we have proposed shifting the emphasis of statemaking policy analysis from the tension between metropoles and colonies (or a dysfunctional emergence of postcolonial nations) to an urban versus rural conflict over 'moral economies'. The emergence of Spain as a modern nation-state at the beginning of the $19^{\text {th }}$ century results in a series of territorial policies designed to organize and control its territory and resources (Gómez 1992; Scott 1998). Similar territorial initiatives, including disentailment campaigns, were also implemented in other places including Mexico (Padua and Vanneph 1986). The historical analysis of these public interventions on the Pyrenees mountain range reveals the significance of these alterations, and the (national-commercial) urban values (meaning rationales or interests) that informed them (Iriarte-Goñi 2002; Vaccaro 2005).

The impact of modernity, via territorializing policies or via external capitalist investment, did not completely destabilize or annihilate local communities and their way of life. The modernization of western societies resulted in demographic, social and economic decay in most of the Western mountains (McNeill 2003; Molina 2002; Netting 1981; Wylie 1977). In many cases, however, local agency, impaired by this erosion of its potential, succeeded in creatively adapting, negotiating, or rejecting the external stimuli brought by the expansion of modern states or the eruption of capitalistic markets (Frigolé 2007; Gil 2000; Iriarte-Goñi 2002; Vaccaro 2007). Several of the examples provided in the paper suggest that the emergence of these external processes actually sharpened local creativity, providing new tools, adapting them to local logics, and resulting in new managerial institutions.

The identification of some of the main social and economic transformations currently sweeping across urban western societies provides scholars with an interpretative clue for analysing some interesting phenomena taking place in the mountains. Our globalized economies are displacing primary and secondary economic sectors overseas, while the national economic structures are focusing on the tertiary sector, often leisure and service industries (Harvey 2006; Inglehart 1997; Sassen 2006). In the mountains this process has crystallized in conservation areas, ski resorts and second residences. In all cases, these policies or initiatives are designed to cover urban needs and are informed by urban values (Darby 2000; Cronon 1991). The historical contextualization of this state-sponsored wave of territorial reorganization of the mountains is a continuation of a long saga of territorialization policies. It allows us to describe it as an unfinished process of transformation. The incorporation of the European Union as a political actor with jurisdiction over conservation policies (Murray 2007; Welch-Devine 2007), or the effects of a unified European real estate market (Perramond 2007) is making this process of transformation still more complicated and more 
dependent on networks of political and economic power that are of urban origin (Shivaramakrishnan and Agrawal 2003).

Conservation has therefore become a major ideological player in the political discourse of modern states (whether metropolitan or postcolonial). It implies a series of values that provide legitimacy to public agency (Cederlöf and Shivaramakrishnan 2006). The conservation rationale is a powerful ideological tool because it brings together several important trends:

a) In Western societies there is generalized consciousness of environmental crises, and any conservation initiative is seen as an attempt to address such crises. In other words, the environment has been integrated in the modern collective psyche as a collective good and its protection is explained as benefiting everybody.

b) Modern society, for the most part living in overcrowded cities, craves and consumes such protected environments. Ecotourism has become an important and profitable economic sector.

c) Conservation policies are also seen as potential tools to foster local development in marginal areas.

These three elements that combine legitimacy with profitability make conservation policies a primary governmental technology (Zimmerer 2006). Globalization is not only resulting in processes of deterritorialization. Modern states are not losing their grip on their own space, people and resources, but in fact quite the opposite (Sparke 2005). States, by reintroducing extinct predators such as wolves or bears, are recreating themselves and their environments, and by declaring entire mountain ranges as protected areas they are redesigning the future of their montane landscapes and the communities that still inhabit them.

The emergence of the European Union as a player in the conservation policies arena does not imply a deterritorialization of conservation. It results in a strengthening of the territorializing effort, and on a reinforcement of the legal and ideological backing of the state agency.

Lastly, the fact that most protected wildlife do not recognize or respect administrative lines and park boundaries, results in these animals crossing beyond protected areas. As they must be preserved even outside them, the conservationist jurisdiction expands to the whole region. These fugitive animals, de facto, extend the jurisdiction of the state from a territorially bounded model, based on archipelagos of protected areas, to a mobile situation in which the environmental administration, on a case by case basis, achieves a certain level of control over non-protected areas too.

\section{Bibliography}

Agamben, G. 1998. Homo sacer: sovereign power and bare life. Palo Alto: Stanford University Press. Agrawal, A. 2005. Environmentality. Durham, NC: Duke University Press.

Altieri, M. 1995. Agroecology: the science of sustainable management. Boulder, CO: Westview Press. Attali, J. 1982. Histoires du temps. Paris: Fayard.

Ayuda, M.I. and Pinilla, V. 2002. El proceso de desertización demográfica en la montaña pirenaica el largo plazo: Aragón. Ager. Revista de Estudios de Despoblación y Desarrollo Rural 2: 1001-1138.

Beltran, O. and Vaccaro, I. 2008. Els comunals al Pallars Sobirà: els usos tradicionals de la muntanya en el marc dels espais naturals protegits. Revista d'Etnologia de Catalunya 33: 142-149.

Bestard, J. and Contreras, J. 1987. Bárbaros, paganos, salvajes y primitivos. Una introducción a la Antropología. Barcelona: Barcanova.

Bjerke, T., Retan, O. and Kellert, S. 1998. Attitudes towards wolves in southeastern Norway. Society and Natural Resources 11 (2): 169-179.

Blaikie, P. 1989. Environment and access to resources in Africa. Africa. 59 (10): 18-40.

Bremner, Ch. and Tourres, M. 2008. Carla Bruni's support for brown bears angers Pyrenean farmers. The Times, London, August $20^{\text {th }}$.

Bryant, R.L. and Bailey, S. 1997. Third world political ecology. London: Routledge.

Burgeño, J. 2000. La divisió territorial. In Vilagrasa, J. (ed.) Transformacions territorials a Catalunya (segles $X I X-X X)$. Lleida: Pagès.

Casanova, E. 1997. L'ós del Pirineu: crònica d'un extermini. Lleida: Pagès.

Castells, M. 1996. The Rise of the Network Society. Malden: Blackwell Publishers.

Cederlöf, G. and Sivaramakrishnan, K. 2006. Ecological nationalisms. Seattle: University of Washington Press.

Certeau, M. 2002. The practice of everyday life. Berkeley: University of California Press. 
Chackrabarty, D. 2000. Provincializing Europe. Princeton: Princeton University Press.

Cronon, W. 1991. Nature's metropolis: Chicago and the Great West. New York: Norton.

Darby, W. 2000. Landscape and identity: geographies of nation and class in England. Oxford: Berg.

Escobar, A. 1995. Encountering development: the making and unmaking of the Third World. Princeton: Princeton University Press,.

Escobar, A. 2008. Territories of difference: place, movements, life, redes. Durham, NC: Duke University Press.

Fairhead, J. and Leach, M. 1996. Misreading the African landscape: society and ecology in a forestsavanna mosaic. Cambridge University Press.

Ferguson, J. 1994. The anti-politics machine: "development", depolitization, and bureaucratic power in Lesotho. Minneapolis: University of Minnesota Press.

Forman, R.T. 1995. Land mosaics: the ecology of landscapes and regions. Cambridge University Press.

Foucault, M. 1991. Governmentality. In Burchell, G., Gordon, C., and Miller, P. (eds.) The Foucault Effect. University of Chicago Press, Chicago.

Foucault, M. 2007 (1978). Security, territory, population: lectures at the Collège de France 1977-78. New York: Palgrave Macmillan.

Foucault, M. 2008 (1978). The Birth of Biopolitics: lectures at the Collège de France 1977-78. Palgrave Macmillan, New York.

Frigolé, J. 2007. Los modelos de lo rústico, lo salvaje y lo silvestre y la identidad de un valle del entorno del Cadí (Alt Urgell). In Vaccaro, I. and Beltran, O. (eds.) Ecología política de los Pirineos. Tremp: Garsineu.

Gellner, E. 1983. Nations and nationalism. Oxford: Basil Blackwell.

Gil, X. 2000. La desamortització dels béns comunals al Pallars Sobirà. Tremp: Garsineu.

Gómez, J. 1992. Ciencia y política de los montes españoles (1848-1936). Madrid: ICONA.

Habermas, J. 1991. The philosophical discourse of modernity. Cambridge MA: MIT Press.

Hannah, M. 2000. Governmentality and the mastery of territory in nineteenth century America. Cambridge University Press.

Haraway, D. 1991. Simians, cyborgs, and women: the reinvention of nature. London: Routledge.

Hardt, M. and Negri, A. 2000. Empire. Harvard University Press.

Harvey, D. 2006. Spaces of global capitalism: towards a theory of uneven geographical development. London: Verso.

Heterington, K. 1997. The badlands of modernity: heterotopia and social ordering. London: Routledge.

Hobsbawm, E. 1968. Laboring men: essays on the history of labor. London: Weidenfeld and Nicolson.

Inglehart, R. 1997. Modernization and postmodernization: cultural, economic, and political change in 43 societies. Princeton: Princeton University Press.

Iriarte-Goñi I., 2002. Common lands in Spain, 1800-1995: persistence, change and adaptation. Rural History 13 (1): 19-37.

Jiménez, S. 1999. Patrimoni i turisme de muntanya a Catalunya: el cas del Pallars Sobirà, una aproximació des de l'antropologia social. Lleida : Universitat de Lleida.

Knight, J. 2006. Waiting for wolves in Japan: an anthropological study of people-wildlife relations. Honolulu: University of Hawai'i Press.

Kriedte, P., Medick, H. and Schlumbohm, J. 1986. Industrialización antes de la industrialización. Barcelona: Crítica.

Martinussen, J. 1997. Society, state and market. London: Zed Books.

McCarthy, J. 2002. First world political ecology: lessons from the wise use movement. Environment and Planning A 34 (7): 1281-1302.

McNeill, J. 2003. The mountains of the mediterranean world. Cambridge University Press.

Mech, D. 1991. Returning the wolf to Yellowstone. In Keiter, R. and Boyce, M. (eds.). The Greater Yellowstone ecosystem: redefining America's wilderness heritage. New Haven: Yale University Press.

Mitchell, T. 1991. Colonizing Egypt. Berkeley: University of California Press.

Molina, D. 2002. El proceso de desertización demográfica de la montaña pirenaica en el largo plazo: Cataluña. Ager. Revista de Estudios sobre Despoblación y Desarrollo Rural 2: 81-100. 
Murray, S. 2007. La propiedad comunal vasca y el estado francés. In Vaccaro, I. and Beltran, O. (eds.) Ecología política de los Pirineos. Tremp: Garsineu.

Netting, R. M. 1981. Balancing on an Alp: ecological change and continuity in a Swiss mountain community. Cambridge University Press.

Neumann, R. 1998. Imposing wilderness: struggles over livelihood and nature preservation in Africa. Berkeley: University of California Press.

Padua, J. and Vanneph, A. 1986. Poder local, poder regional. Mexico DF: El Colegio de México.

Peluso, N. and Vandergeest, P. 2001. Genealogies of the political forest and customary rights in Indonesia, Malaysia and Thailand. Journal of Asian Studies 60 (3): 761-812.

Perramond, E. 2007. Localismo como nacionalismo en los Pirineos Orientales. In Vaccaro, I. and Beltran, O. (eds.) Ecología política de los Pirineos. Tremp: Garsineu.

Polanyi, K. 1944. The Great Transformation. New York: Holt, Rinehart and Winston.

Pred, A. 1986. Place, practice and structure: social and spatial transformation in Southern Sweden 17501850. Lanham: Rowman and Littlefield.

Robbins, P. 2002. Obstacles to a first world political ecology? Looking near without looking up. Environment and Planning A 34 (8): 1509-1513.

Sabartés, J.M. 1998. Població i territori a l'Alt Pirineu català. Tremp: Garsineu.

Sabaté, F. 1997. El territori a la Catalunya medieval. Barcelona: Salvador Vives Casajuana.

Sabetti, F. 2002. Village politics and the mafia in Sicily. Montreal: McGill University Press.

Sahlins, P. 1991. Boundaries: the making of France and Spain in the Pyrenees. Berkeley: University of California Press.

Sassen, S. 2006. Territory, authority, rights: from medieval to global assemblages. Princeton: Princeton University Press.

Scott, J. 1985. Weapons of the weak. New Haven: Yale University Press.

Scott, J. 1998. Seeing Like a State. New Haven: Yale University Press.

Sivaramakrishnan, K. 1999. Modern forests: statemaking and environmental change in colonial Eastern India. Oxford University Press.

Sivaramakrishnan, K. and Agrawal, A. (eds.) 2003. Regional modernities. Oxford University Press.

Smith, N. 1990. Uneven development: nature, capital and the production of space. Oxford: Blackwell.

Sparke, M. 2005. In the space of theory. Minneapolis: University of Minnesota Press.

Terradas, I. 1979. La colònia industrial com a particularisme històric. Barcelona: Laia.

Thompson, E.P. 1968. The making of the English working class. London: Peter Smith Publisher.

Thomson, J. 1992. A distinctive industrialization: cotton in Barcelona 1728-1832. Cambridge University Press.

Vaccaro, I. 2005. Property mosaic and state-making: governmentality, expropriation and conservation in the Pyrenees. Journal of Ecological Anthropology 9: 4-19.

Vaccaro, I. 2007. Sovereignty, collective ingenuity and moral economies: the confluence of transnational trends, states and local strategies in the Pyrenees. Environment and History 13 (1): 25-46.

Vaccaro, I. and Beltran, O. 2007a. Consuming space, nature and culture: patrimonial discussions in the hyper-modern era. Journal of Tourism Geographies 9 (3): 254-274.

Vaccaro, I. and Beltran, O. (eds.) 2007b. Ecología política de los Pirineos. Tremp: Garsineu.

Walker, P. 2003. Reconsidering 'regional' political ecologies: toward a political ecology of the rural American West. Progress in Human Geography 23 (1): 7-24.

Wallerstein, I. 1974. The modern world-system: capitalist agriculture and the origins of the European world-economy in the sixteenth century. New York: Academic Press.

Weber, M. 1978. Economy and society. Berkeley: University of California Press.

Welch-Devine, M. 2007. Localidad e influencias globales: el pastoreo en Sola y las regulaciones de la Unión Europea. In Vaccaro, I. and Beltran, O. (eds.) Ecología política de los Pirineos. Tremp: Garsineu.

West, P. 2006. Conservation is our government now: the politics of ecology in Papua New Guinea. Durham: Duke University Press.

West, P., Igoe, J., and Brockington, D. 2006. Parks and peoples: the social impact of protected areas. Annual Review of Anthropology 35: 251-77.

Wylie, L. 1977. Village in the Vaucluse. Harvard University Press.

Zimmerer, K.S. 2006. Globalization and new geographies of conservation. University of Chicago Press. 


\begin{abstract}
In this paper, using a political ecology framework, we examine the impacts of statemaking technologies in several areas of the Pyrenean mountain range, Spain. We describe processes of governmental territorialization in a European, non-colonial setting, stressing their effect on the conceptualization and management of natural resources. Conservation policies are a traditional locus of political ecology: as public policies devoted to natural resource management they embody the interaction between politics and ecology. The article has several analytical goals: a) to shift the emphasis of the political ecological analysis from an explanation of territorialization based on the tension between the first and third world, towards the impact of the conflictive relationship between cities and rural areas, b) to highlight the resilience and creativity of local agency in the face of massive political disruption in the form of public policies, c) to point out to the emergence of European policies and the new leisure economies as key elements of the contemporary reconstruction of the Western mountains, and d) underscore the unfinished character, or the ongoing nature, of the described process of political negotiation of rights of access and control of natural resources.
\end{abstract}

Key Words: political ecology; Pyrenees; conservation; territorial control

\title{
Resumen
}

En este artículo examinamos, utilizando el marco teórico de la ecología política, los impactos de tecnologías estatales en diversas zonas de los Pirineos españoles. Describimos los procesos de territorialización gubernamental en un contexto no colonial, europeo, enfatizando su efecto en la conceptualización y la gestión de los recursos naturales. Las políticas de conservación son un tema de interés tradicional para la ecología política: en tanto que políticas públicas dedicadas a la gestión de los recursos naturales, se manifiestan como la materialización de la interacción entre política y ecología. El artículo tiene distintos objetivos analíticos: a) trasladar el énfasis del análisis de los procesos de territorialización desde una explicación basada en la tensión entre el primer y el tercer mundo, a otra que prioriza la tensa relación entre lo urbano y lo rural; b) señalar la resiliencia y la creatividad de las poblaciones locales frente a las disrupciones políticas masivas generadas por la implementación de políticas públicas; c) apuntar a la emergencia de las políticas europeas y las nuevas economías del ocio como elementos clave para la reconstrucción contemporánea de las montañas occidentales; y d) remarcar la naturaleza inacabada, o en flujo, del proceso descrito de negociación política de los derechos de acceso y control de los recursos naturales.

Palabras clave: la ecología política; Pirineos; conservación; el control territorial

\section{Résumé}

Dans cet article, en utilisant un cadre de l'écologie politique, nous examinons les impacts des technologies de "statemaking" dans le massif des Pyrénées, Espagne. Nous décrivons les processus de territorialisation gouvernementales dans un contexte européen, en soulignant leur effet sur la conceptualisation et la gestion des ressources naturelles. Les politiques de conservation sont un thème classique de l'écologie politique: les politiques publiques consacrées à la gestion des ressources naturelles, la politique de conservation incarnent l'interaction entre le politique et l'écologie. L'article a plusieurs objectifs d'analyse: a) de déplacer l'accent de l'analyse écologique politique vers l'impact de la relation conflictuelle entre les villes et les zones rurales en Europe. b) mettre en lumière la résilience et la créativité des populations locales face à la désorganisation politique massive par les politiques publiques. c) de signaler que les politiques européennes et les économies touristiques nouvelles sont des éléments clés de la reconstruction contemporaine de la chaîne des Pyrénées occidentales, et d) soulignent le caractère inachevé, ou le caractère continu, de la négociation politique des droits d'accès et de contrôle des des ressources naturelles.

Mots-clés: écologie politique; Pyrénées, la conservation; contrôle territorial 